\title{
Variability of thermal and precipitation conditions in the growing season in Poland in the years 1966-2015
}

\author{
Arkadiusz M. Tomczyk ${ }^{1} \cdot$ Katarzyna Szyga-Pluta $^{1}$ \\ Received: 12 October 2017 / Accepted: 5 March 2018 / Published online: 19 March 2018 \\ (C) The Author(s) 2018
}

\begin{abstract}
The aim of the study was to identify the thermal and precipitation conditions and their changes in the growing season in Poland in the years 1966-2015. Data on average daily air temperature and daily precipitation totals for 30 stations from the period of 19662015 were used. The data were obtained from the collections of the Institute of Meteorology and Water Management - National Research Institute. The growing season was defined as the period of average daily air temperature $\geq 5{ }^{\circ} \mathrm{C}$. The mathematical formulas proposed by Gumiński (1948) were used to determine its start and end dates. In the growing season in Poland in the years 1966-2015, there were more significant changes in the thermal conditions than there were in the precipitation conditions. In terms of long-term trends over the study period, thermal conditions during the growing season are characterised by an increase in mean air temperature, an increase in the sum of air temperatures and an increasing occurrence of seasons classified as abovenormal seasons. Precipitation conditions of the growing season show large temporal and spatial variations in precipitation and a predominance of normal conditions. The changes in precipitation were not statistically significant, except for Świnoujście.
\end{abstract}

\section{Introduction}

In recent years, an increase in the average global air temperature has been observed. In the northern hemisphere, the 1983-2012 period was probably the warmest 30-year period in the last 1400 years (IPCC 2013). One consequence of the increase in air temperature is an extension of the growing season in Europe, which results in changes in the phenological stages of individual plants (Menzel and Fabian 1999; Chmielewski and Rötzer 2001; Chmielewski et al. 2004). In the coming years, the length of the growing season in Poland is forecast to increase. Nieróbca et al. (2013) indicate that, by 2030, the growing season in central Poland may have increased by $10-$ 14 days over its length during the reference period 1971-2000 and, by 2050 , by $18-27$ days, while in south-western Poland, those increases are forecast to be 11-17 days and 22-30 days, respectively. A similar trend

Arkadiusz M. Tomczyk

atomczyk@amu.edu.pl

1 Department of Climatology, Institute of Physical Geography and Environmental Planning, Adam Mickiewicz University in Poznań, B. Krygowskiego 10, 61-680 Poznań, Poland is predicted by Skaugen and Tveito (2004) for Norway by 2050.

Changes in thermal conditions may, however, also have adverse effects on agriculture (Nieróbca 2009). Reduced productivity of some crops may result from heat stress and deteriorating water balance. Increasing temperature may also promote the development of heat-loving weeds, pests or the emergence of new plant diseases. Changes in the start and end dates and length of the growing season, in addition to the consequences for plant ecosystems, may lead to a longterm increase in carbon storage, and changes in vegetation may affect the climate system (Linderholm 2006).

The aim of the study was to identify the thermal and precipitation conditions in the growing season in Poland in years 1966-2015 and to determine changes in the above conditions in the analysed multi-year period.

\section{Data and methods}

The study was based on daily values of average air temperature and daily precipitation totals for 1966-2015 obtained for 30 stations in Poland (Fig. 1). The data were provided by the Institute of Meteorology and Water Management-National Research Institute. 
Fig. 1 Locations of meteorological stations (grey, mountain areas excluded)

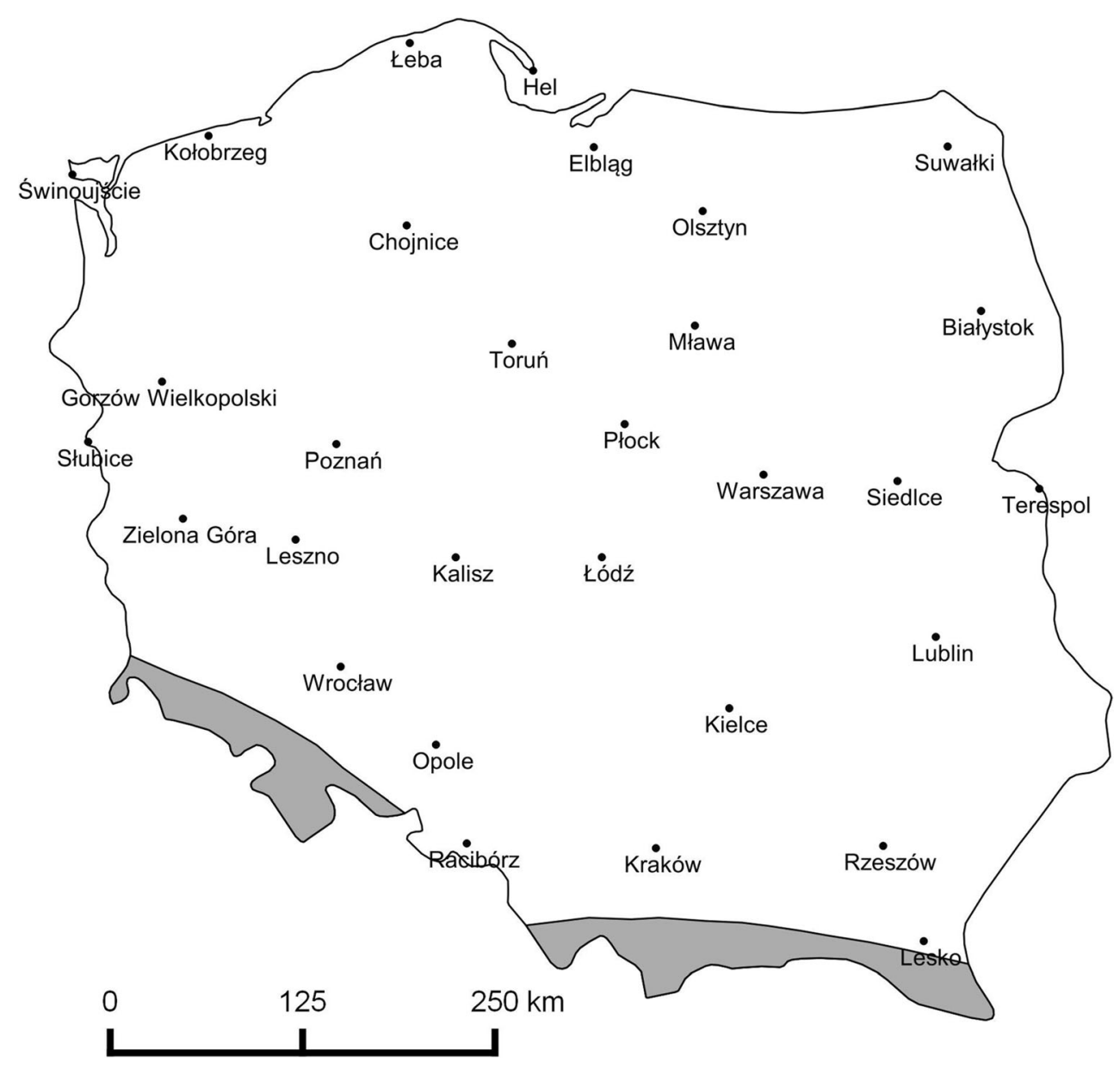

Based on the above data, the start and end dates of the growing season were determined. A period with an average daily air temperature $\geq 5{ }^{\circ} \mathrm{C}$ was considered as a growing season (Carter 1998; Skaugen and Tveito 2004; Linderholm et al. 2008; Szyga-Pluta 2011; Żmudzka 2012; Radzka 2013). The mathematical formulas proposed by R. Gumiński (1948) were used to determine the growing season's start and end dates.

This method assumes the following: monthly average temperature falls on the 15th day of a month; each month has 30 days; and monthly temperature changes are evenly distributed. The formulas used are:

$x=30\left[\left(t p-t_{1}\right) /\left(t_{2}-t_{1}\right)\right]$

$x=30\left[\left(t_{1}-t p\right) /\left(t_{1}-t_{2}\right)\right]$

where

tp Threshold temperature

$t_{1} \quad$ Average temperature in the month preceding the threshold temperature

$t_{2}$ Average temperature in the month following the threshold temperature

$x \quad$ Number of days between the day with the threshold temperature and the 15th day of the preceding month
The number of days calculated on the basis of the above formula is added to the 15th day of the month preceding the threshold temperature. If the desired number is greater than 15 , when adding, one should consider the actual number of days in a given month. The obtained date is the beginning or end of the separated period. The above method is commonly adopted in determining growing seasons and thermal seasons (Skowera and Kopeć 2008; Szyga-Pluta 2011; Kępińska-Kasprzak and Mager 2015; Czernecki and Miętus 2017). It was also used for the variability of seasons in individual years by Kossowska-Cezak (2005). Kępińska-Kasprzak and Mager (2015) compared the thermal vegetation period determined by the method of Gumiński with those determined by the method of Huculak and Makowiec (the latter consists in calculating the accumulated series of deviations of average daily air temperature values from appropriate threshold values) for the period 1966-2005 in Poland and they discussed the possibility of their use to determine the beginning and end of the growing season. They stated that in long-term datasets, both methods lead to similar results, and suggested their comparison with phenological observations and/or vegetation indicators 
obtained by satellite remote sensing. Bartoszek and Siłuch (2015) showed a significant accordance between average vegetation period onsets as determined by both the Gumiński and remote sensing methods in the decade 2001-2010.

In the next step, the average air temperature, the sum of the air temperatures and the sum of precipitation in the growing season in each year were calculated. The actual length of the growing season in particular years was taken into account to calculate these characteristics. Subsequently, the changes in the beginning and the end of the growing season and changes in the air temperature and precipitation totals in the analysed multi-year period were determined. The Mann-Kendall nonparametric test was used to determine the statistical significance $(p<0.05)$. In addition, for selected seasons, anomalies of monthly precipitation totals were calculated. Anomalies were calculated as the difference between the monthly precipitation total in a given year and the average monthly total from the multi-year period.

The thermal conditions were then determined using the thermal classification developed by Lorenc (1994). In this classification, the thermal assessment shall be based on the relationship between the average temperature of the season and the corresponding average value for the multi-year period increased or reduced by a multiple of the standard deviation (Table 1). In turn, the assessment of precipitation conditions was based on the precipitation classification developed by Kaczorowska (1962). In this classification, the precipitation assessment is calculated on the basis of the percentage of precipitation in a given season over the multi-year average (Table 2).

\section{Results}

\subsection{Beginning and end of growing season}

In the years 1966-2015, the growing season in Poland on average started on 26 March and ended on 7 November. The growing season started from the south-west to the north and northeast of Poland (Fig. 2a). The beginning of the period was recorded the earliest in Stubice-18 March and the latest in Suwałki-7 April. In turn, the end of the growing season was from the north-east to the south-west and the coast (Fig. 2b). The end date of the analysed period ranged from 25 October in Suwałki to 16 November in Hel and Łeba. The obtained data indicate that the growing season started the earliest and ended the latest in south-western Poland, while it started the latest and ended the earliest in north-eastern Poland. It follows from this that the vegetation period was the shortest in north-eastern Poland (on average $<209$ days), whereas in south-western and western Poland it was the longest (average $>238$ days) (Fig. 2c). The average length of the growing season for the entire research area was 227 days.

Over the course of the analysed multi-year period, the growing season started progressively early, although significant changes occurred only in northern and north-eastern Poland. On the other hand, the end of the growing season occurred later and later. The recorded changes were statistically significant in the majority of the country except for the north-eastern regions, the Świętokrzyskie Mountains and the Lublin Upland. The consequence of changes in the beginning

Table 1 Scale range of the thermal classification according to Lorenc (1994)

\begin{tabular}{|c|c|}
\hline Thermal class & Threshold values for air temperature \\
\hline extremely warm & $\mathrm{tz}>\mathrm{ts}+2.5 \sigma$ \\
\hline anomalously warm & ts $+2.0 \sigma<t z \leq t s+2.5 \sigma$ \\
\hline very warm & ts $+1.5 \sigma<\mathrm{tz} \leq \mathrm{ts}+2.0 \sigma$ \\
\hline warm & ts $+1.0 \sigma<t z \leq t s+1.5$ \\
\hline slightly warm & ts $+0.5 \sigma<\mathrm{tz} \leq \mathrm{ts}+1.0 \sigma$ \\
\hline normal & ts $-0.5 \sigma \leq t z \leq t s+0.5 \sigma$ \\
\hline slightly cold & ts $-1.0 \sigma \leq \mathrm{t} z<\mathrm{ts}-0.5 \sigma$ \\
\hline cold & ts $-1.5 \sigma \leq t z<t s-1.0 \sigma$ \\
\hline very cold & ts $-2.0 \sigma \leq \mathrm{t} z<\mathrm{ts}-1.5 \sigma$ \\
\hline anomalously cold & ts $-2.5 \sigma \leq t z<t s-2.0 \sigma$ \\
\hline extremely cold & $\mathrm{tz}<\mathrm{ts}-2.5 \sigma$ \\
\hline \multicolumn{2}{|c|}{$\begin{array}{c}\text { ts - average temperature from multi-year period; } \\
\text { tz - average temperature of the season; } \\
\sigma-\text { standard deviation }\end{array}$} \\
\hline
\end{tabular}


Table 2 Scale range of precipitation classification according to Kaczorowska (1962)

\begin{tabular}{|c|l|}
\hline Precipitation class & Threshold value of total precipitation \\
\hline extremely wet & $\mathrm{pz}>150 \mathrm{ps}$ \\
\hline very wet & $\mathrm{pz}=126-150 \% \mathrm{ps}$ \\
\hline wet & $\mathrm{pz}=111-125 \% \mathrm{ps}$ \\
\hline normal & $\mathrm{pz}=90-110 \% \mathrm{ps}$ \\
\hline dry & $\mathrm{pz}=75-89 \% \mathrm{ps}$ \\
\hline very dry & $\mathrm{pz}=50-74 \% \mathrm{ps}$ \\
\hline extremely dry & $\mathrm{pz}<50 \% \mathrm{ps}$ \\
\hline \multicolumn{2}{|c}{$\mathrm{pz}-$ seasonal precipitation total; } \\
\hline ps - average seasonal precipitation total in the analysed multi-year period \\
\hline
\end{tabular}

and end of the growing season was that it became longer, with the maximum extension occurring on the coast. Except for two stations in the south of the country, the changes were statistically significant (Fig. 3). The dates of the growing season's beginning and ending, and its length are very variable from year to year. However, the average start date in Poland had a greater tendency to move earlier through the research period, while the end date end occurred progressively later at a slower pace. Hence, the length of the growing season tended to become longer throughout the period. a

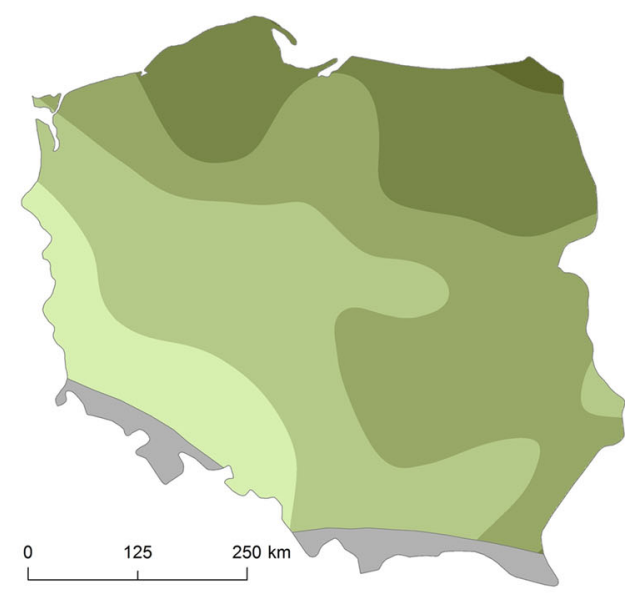

$\square<21.03$

$\square 21.03-26.03$ $\square 27.03-31.03$ $01.04-05.04$ - $>05.04$ b

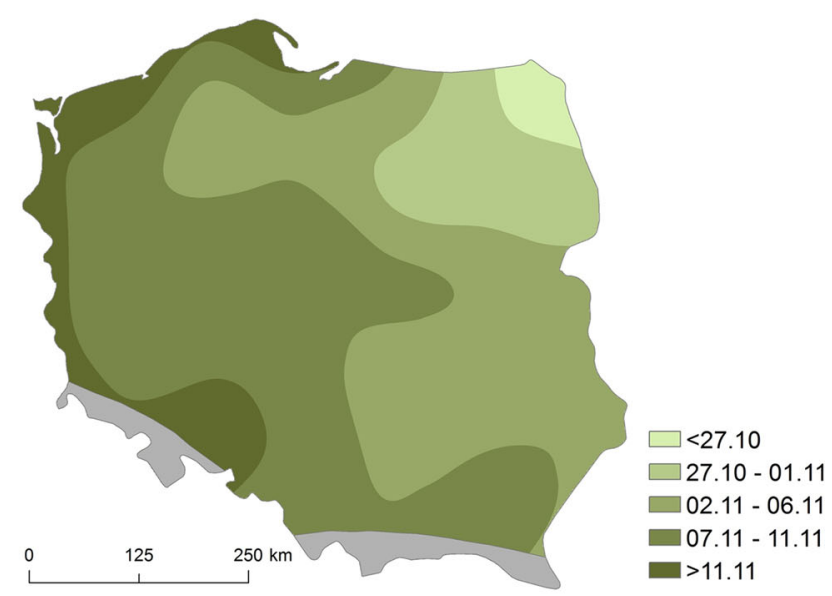

C

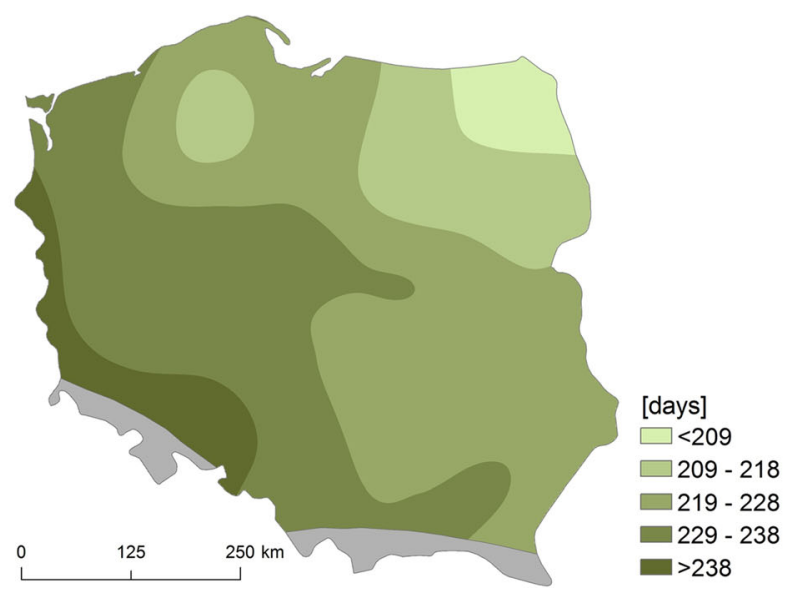

Fig. 2 Average growing season start date (a), end date (b) and length (c) in Poland in the years 1966-2015 


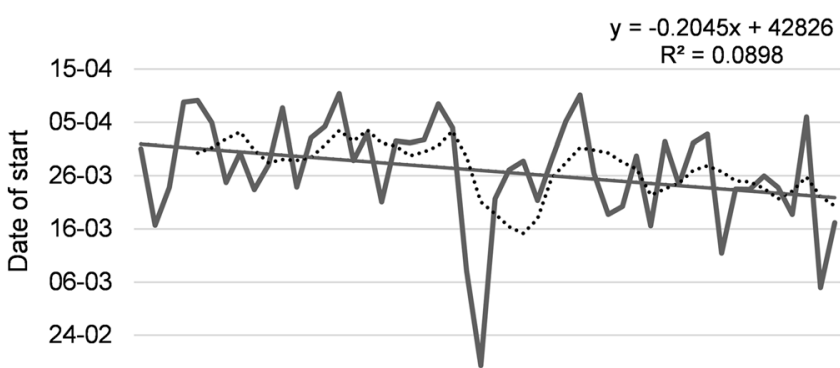

14-02

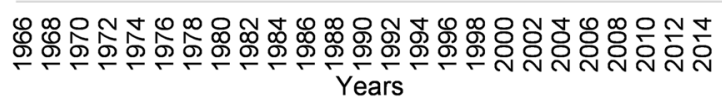

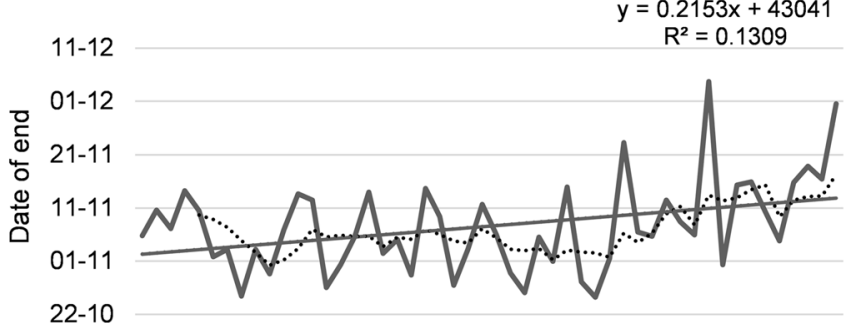

$12-10$

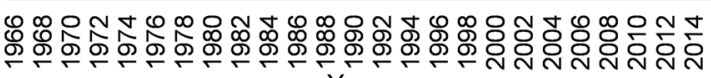
Years

$y=0.4198 x+215.98$ $\mathrm{R}^{2}=0.1916$

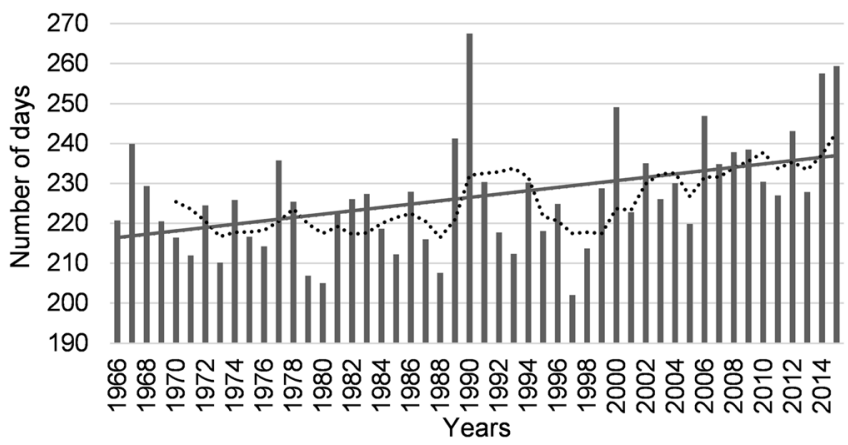

Fig. 3 Growing seasons' average start date (a), end date (b) and length (c) in the years 1966-2015 in Poland (5-year moving average, solid line; linear trend, dotted line)

\subsection{Thermal conditions of the growing season}

The average air temperature in the growing season in Poland in the years $1966-2015$ was $13.1^{\circ} \mathrm{C}$. In the majority of the country, the average air temperature was relatively even and was in the range $13.0-13.6^{\circ} \mathrm{C}$ (Fig. 4a). An air temperature below $13.0^{\circ} \mathrm{C}$ was recorded only on the coast. The course of the average annual air temperature shows considerable yearto-year fluctuations, although this variation is similar within the analysed area, as evidenced by the small variance of the standard deviation values, which range from $0.5^{\circ} \mathrm{C}$ at seaside stations up to $0.8{ }^{\circ} \mathrm{C}$ in Suwałki. Based on the average air temperature for the whole area, it was found that the coldest season occurred in 1978, during which, $43 \%$ of the stations experienced their lowest air temperature for the whole multiannual period. The average air temperature for the whole area was $11.7^{\circ} \mathrm{C}$. In the analysed season, north-eastern Poland and the Kashubian Lake District should be considered the coldest regions (Fig. 4b). The lowest air temperature was recorded in Suwałki, at only $11.0{ }^{\circ} \mathrm{C}$. On the other hand, it was the warmest in the west, south-west and south of the country, and the highest air temperature was recorded in Poznań $\left(12.2{ }^{\circ} \mathrm{C}\right)$. At $63 \%$ of the stations, the coldest seasons occurred in the decade of 1976-1985, while in the next 10 years, the 1990 season was equally cold. However, the warmest season was found in 2011 , with an average air temperature of $14.0^{\circ} \mathrm{C}$. This season was the coldest in northern Poland, especially on the coast (Fig. 4c). The lowest average air temperature was recorded in Hel $\left(12.8^{\circ} \mathrm{C}\right)$ and Leba $\left(12.9^{\circ} \mathrm{C}\right)$. On the other hand, the warmest regions were found in central, western and eastern Poland, where the air temperature exceeded $14.0^{\circ} \mathrm{C}$, and its highest values were recorded in Poznan and Słubice $\left(14.6{ }^{\circ} \mathrm{C}\right)$. The 2011 season was the warmest season in the analysed multi-year period for ten stations. At $83 \%$ of stations, the warmest growing season occurred after 2000, and at 16 stations, it has occurred in the last 10 years.

An increase in air temperature during the growing season was observed in Poland, although not everywhere was the increase statistically significant (Fig. 4d, 5). Apart from northern Poland and the vicinity of Płock and Białystok, the observed changes were statistically significant at a level of at least 0.05 . The highest increase in air temperature was recorded in southern Poland, with the maximum in Rzeszów $\left(0.26{ }^{\circ} \mathrm{C} / 10\right.$ years $)$ and Kraków and Wrocław $\left(0.25{ }^{\circ} \mathrm{C} /\right.$ 10 years) (Fig. 5 ).

The average sum of temperatures in Poland during the growing season was $2979^{\circ} \mathrm{C}$. Its highest values were recorded in south-western Poland, where it exceeded $3200^{\circ} \mathrm{C}$ (Fig. 6a). The lowest sums were recorded in north-eastern Poland and the Kashubian Lake District, below $2700{ }^{\circ} \mathrm{C}$. The coldest, in terms of the sums of air temperature was the 1980 season, with a mean sum of $2510{ }^{\circ} \mathrm{C}$. The highest sums were recorded in the south-west of the country, where they exceeded $2600{ }^{\circ} \mathrm{C}$ (Fig. 6b). In contrast, the coldest regions included north- 

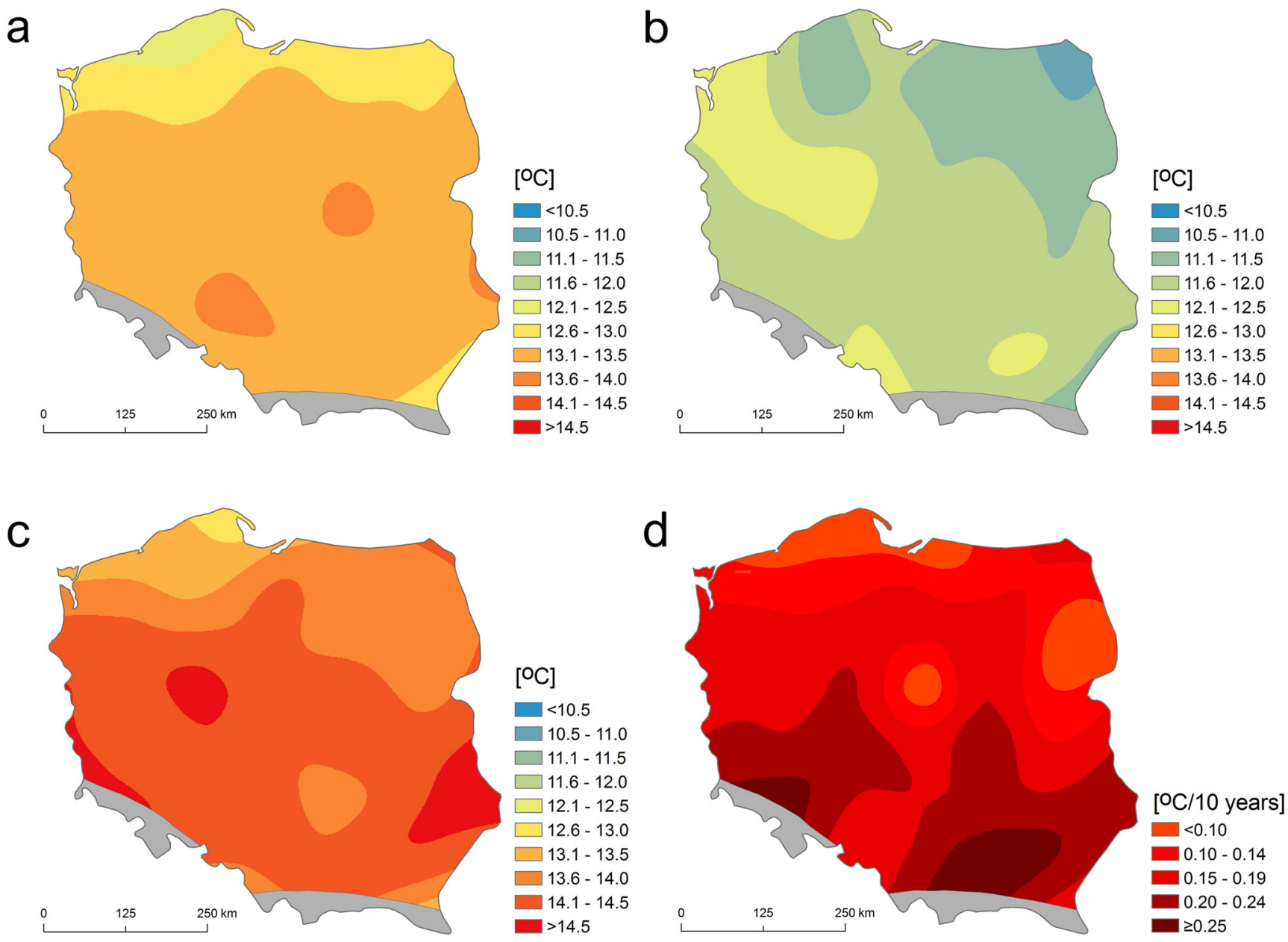

Fig. 4 Average air temperature in the growing season in Poland in 1966-2015 (a), in 1978 (b), in 2011 (c) and change of air temperature (d)

eastern Poland, the Kashubian Lake District and the Świętokrzyskie Mountains. In that season, 24 stations had their lowest sum of air temperatures of the whole multi-year period. At the same time, this season was one of the shortest of the whole study period for most stations, and the very shortest for seven stations. The warmest season, on the other hand, was recorded in 2014, with an average sum of $3429^{\circ} \mathrm{C}$. In Poland, the thermal conditions were significantly diverse (Fig. 6c). As in the case of the coldest season, the highest sums were recorded in the south-western and western regions of the country, where they exceeded $3800{ }^{\circ} \mathrm{C}$, while in north-eastern Poland, they did not exceed $3000{ }^{\circ} \mathrm{C}$. In the abovementioned season, 17 stations experienced their highest sum of air temperatures of the entire multi-year period. At most stations, this season was one of the longest seasons in the years studied, and at three stations, it was the very longest. In the examined period, a statistically significant increase in sums of air temperatures in Poland was found (Fig. 6d). The smallest changes took place in north-eastern Poland with a minimum in Białystok, $57.5^{\circ} \mathrm{C} / 10$ years (Fig. 7). Much more significant changes occurred in western and southern Poland, and their maximum was found in Wrocław at $123.4{ }^{\circ} \mathrm{C} /$ 10 years.

Based on the thermal classification developed by Lorenc (1994), it was found that normal conditions prevailed in the analysed years (Table 3 ). On the basis of averaged data for the whole area, it was stated that normal seasons constituted $48 \%$ of all seasons. Over the last 20 years, there has been a noticeable increase in slightly warm and warm seasons, with no season being below normal. The last season that was colder than average occurred in 1991. Thermal conditions at individual stations differed slightly from the average. The most frequent occurrence of normal conditions, the share of which ranged from $36 \%$ in Chojnice to $56 \%$ in Rzeszów, is their common feature. In the years 1966-1995, colder seasons were visibly more frequent than warmer seasons, and their ratio ranged from 9:10 in Płock to 4:13 in Kalisz. In the aforementioned 30 years, significantly colder seasons were recorded in 1974, 1977, 1978 and 1990, which were generally classified as very cold, anomalously cold and even extremely cold seasons in the eastern regions of the country. One can also distinguish the seasons clearly above the standard in the analysed 


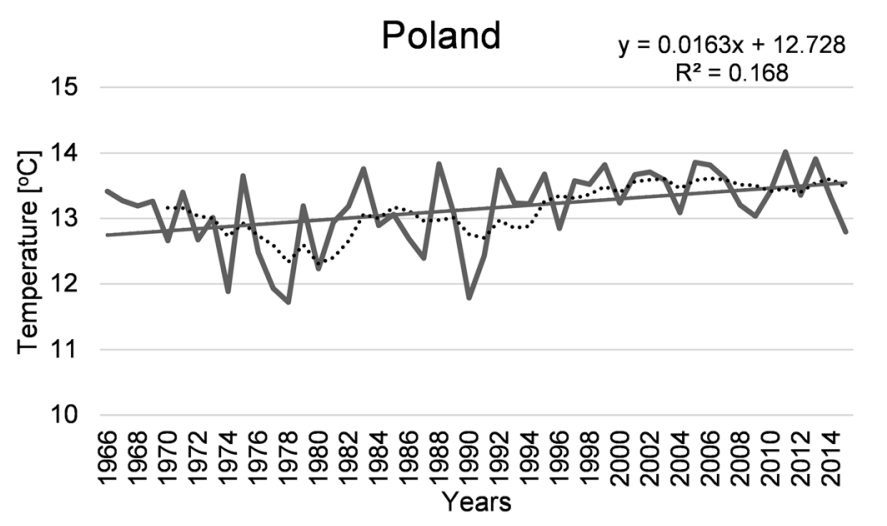

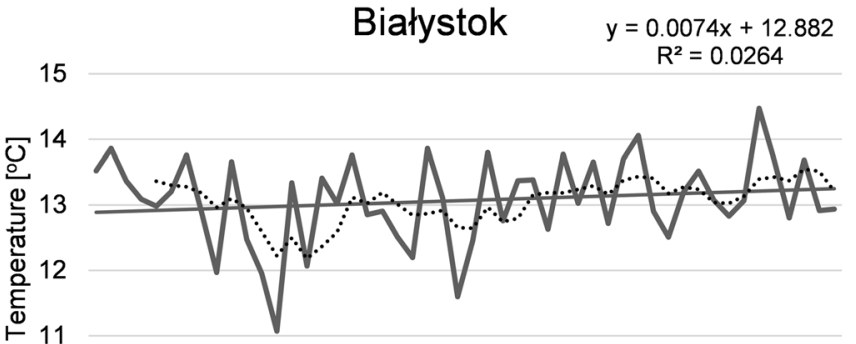

10

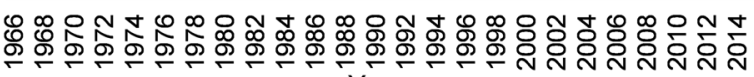
Years

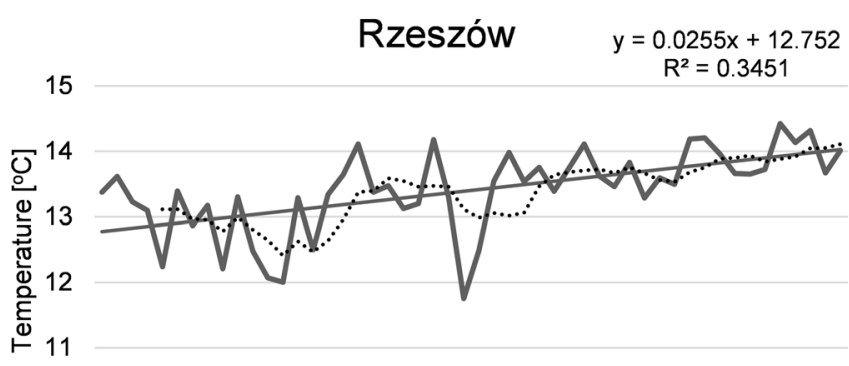

10

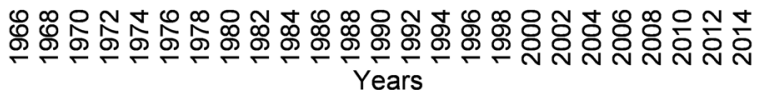

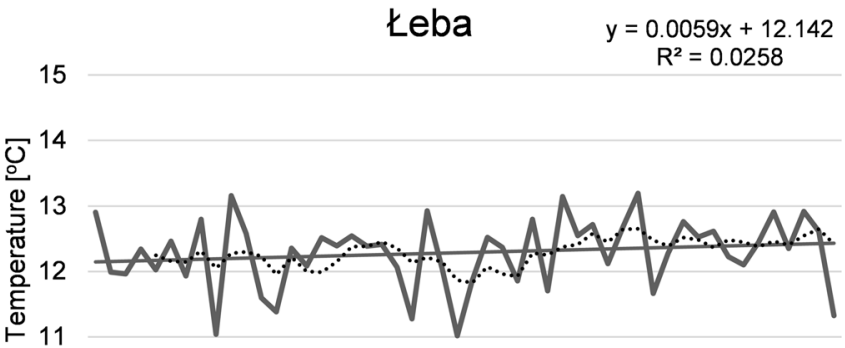

10

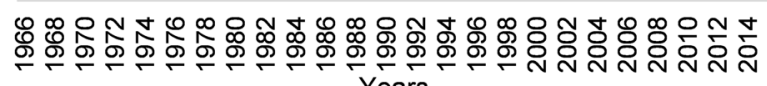
Years

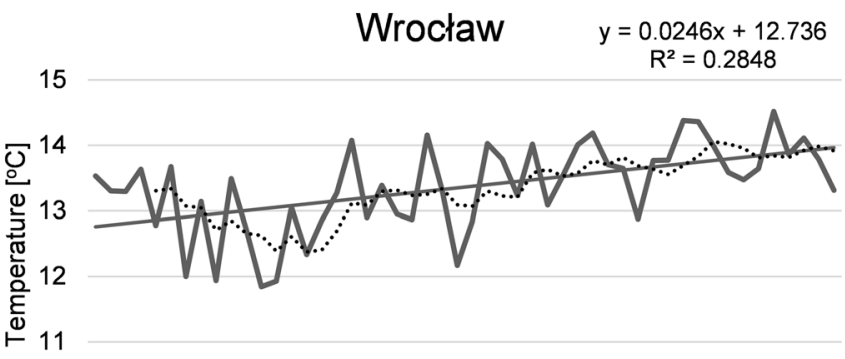

10

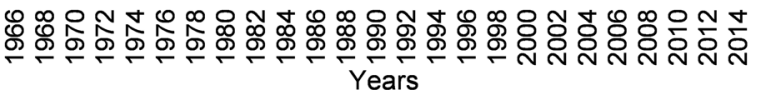

Fig. 5 Average air temperature in the growing season in the years 1966-2015 at selected stations in Poland (5-year moving average, solid line; linear trend, dotted line)

multi-year period, among others, in 1975, 1983, 1988, 1992 and 1995 perceived mostly as slightly warm and warm as well as occasionally very warm seasons, e.g., in Hel, Łeba (1975), Opole (1983, 1988), Suwałki (1992) and Świnoujście (1966). In all stations, there was a marked increase observed in the frequency of seasons above normal in the past 20 years, with a simultaneous decrease in seasons falling below normal. In the aforementioned multi-year period, in addition to the frequently occurring slightly warm, warm and very warm seasons, there were also anomalously warm seasons in Białystok (2010), Chojnice (2003), Kalisz (2007), Kielce (2003), Lesko (2007), Słubice (2011), Suwałki (2003) and Toruń (1999). In spite of significant warming, seasons below the standard have also been recorded in recent years. Against the background of the last 20 years, the season of 2015 is distinguished in particular, which, in north-western Poland above all was classified as slightly cold, cold and even very cold in Hel and Łeba.

\subsection{Precipitation conditions of the growing season}

In the years 1966-2015, the average seasonal precipitation total in Poland during the growing season was $430.4 \mathrm{~mm}$. The highest precipitation totals were recorded in southern and northern Poland, while the lowest was in central regions (Fig. 8a). The course of seasonal precipitation totals shows large fluctuations from year to year. This variability is diverse in the examined area, as 
a

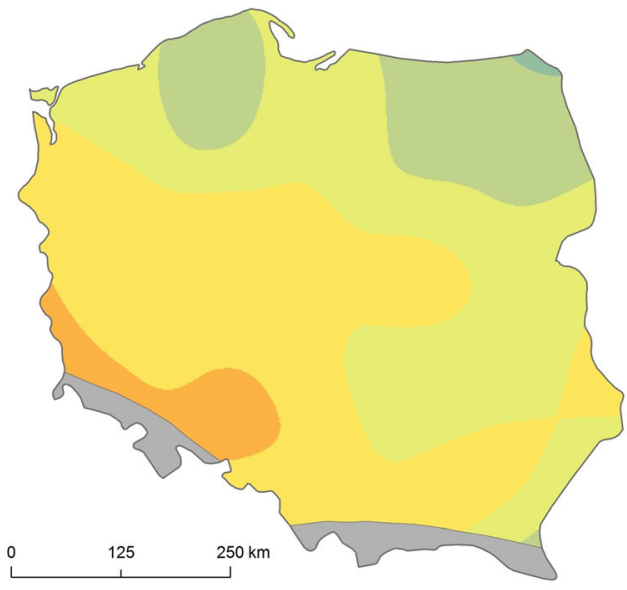

$[\mathrm{C}]$

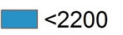

- $2200-2400$

$\square 2401$ - 2600

$\square 2601-2800$

$\square 2801$ - 3000

$\square 3001-3200$

$\square 3201$ - 3400

- $3401-3600$

$3601-3800$

$>3800$

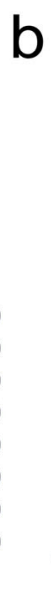

0
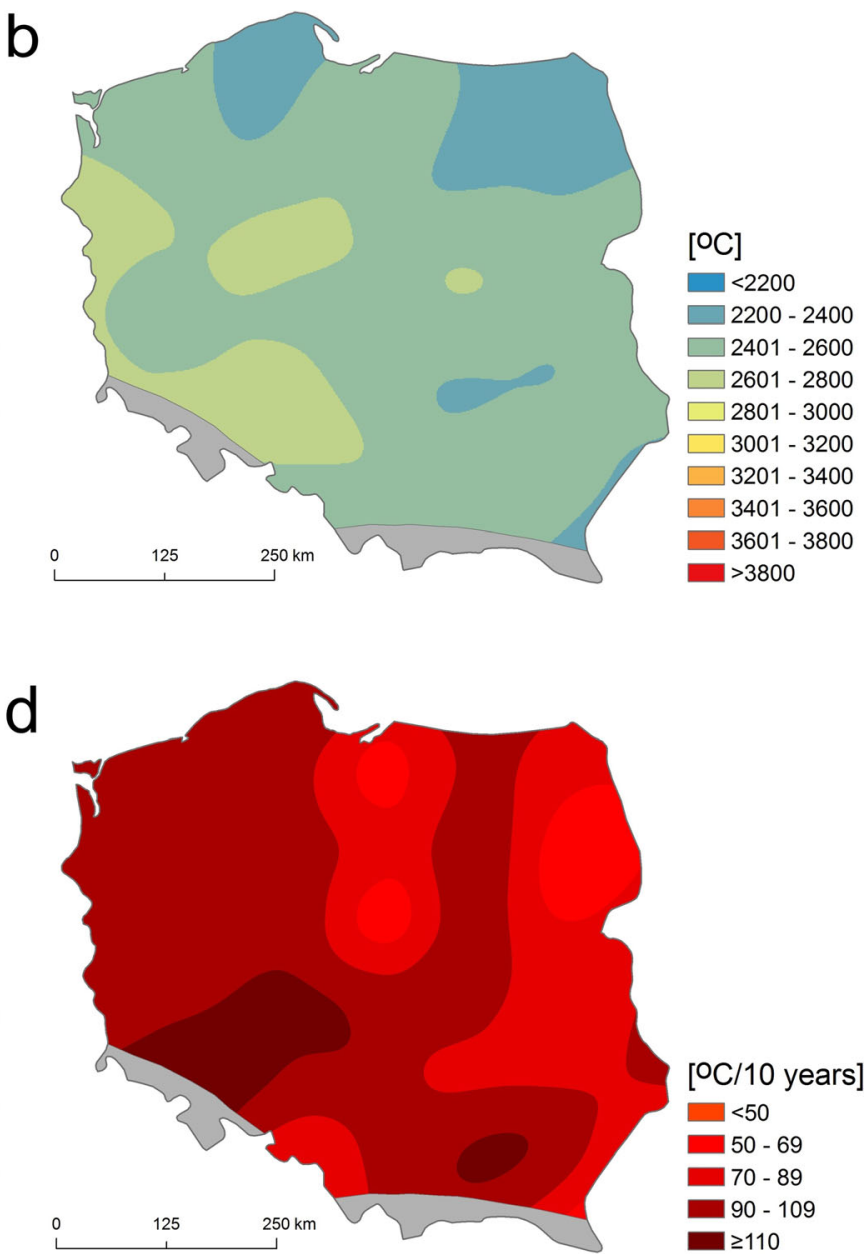

Fig. 6 Average sum of temperatures in the growing season in Poland in 1966-2015 (a), sum in 1980 (b), sum in 2014 (c) and change of sum of temperatures (d)

evidenced by the standard deviations, which range from $72.7 \mathrm{~mm}$ in Gorzów Wielkopolski to $112.4 \mathrm{~mm}$ in Racibórz. Based on average precipitation totals for the entire area, it was found that the driest season occurred in 1982, with an average total of $281.6 \mathrm{~mm}$. This season was driest in the Wielkopolska Lakeland and the eastern part of the South Pomeranian Lakeland, and the lowest rainfall total was recorded in Poznań at only $168.4 \mathrm{~mm}$ (Fig. 8b). A precipitation total below $200 \mathrm{~mm}$ was also recorded in Chojnice (195.9 mm). On the other hand, the highest amount of rainfall in this season occurred in the south-eastern regions of the country with the maximum in Lesko, which was as many as $459.0 \mathrm{~mm}$. In the 1982 season, nine stations experienced their driest season of
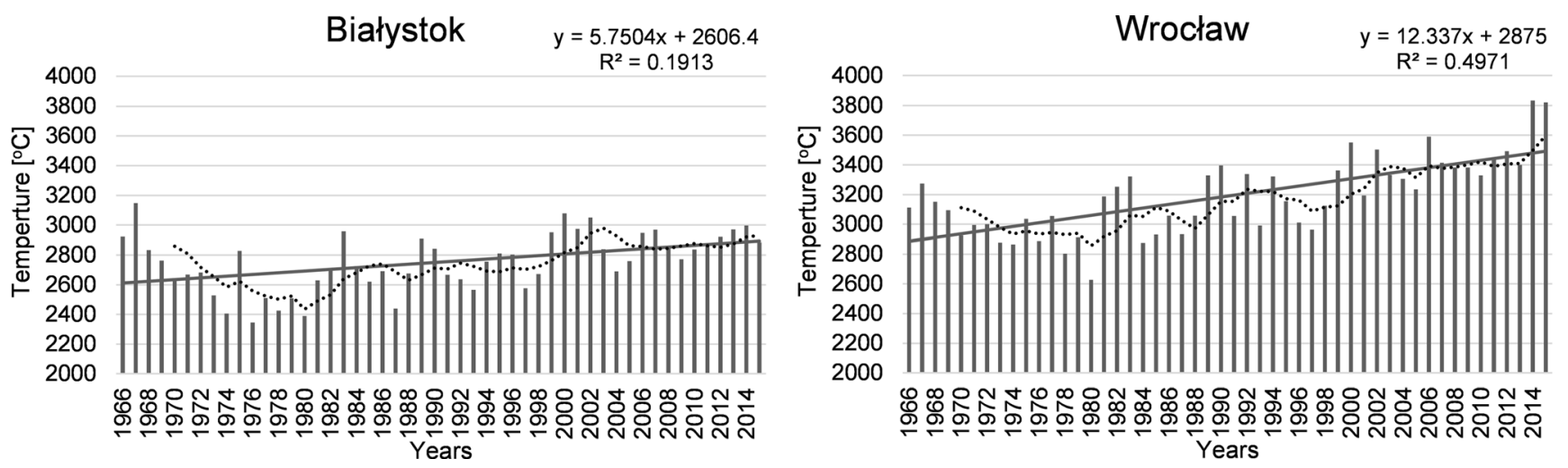

Fig. 7 Sum of air temperatures in the growing season at selected stations in Poland in 1966-2015 (5-year moving average, solid line; linear trend, dotted line) 
Table 3 Thermal classification of the growing season in Poland in the years 1966-2015

\begin{tabular}{|c|c|c|c|c|c|c|c|c|c|}
\hline Year & $\mathrm{T}$ & Year & $\mathrm{T}$ & Year & $\mathrm{T}$ & Year & $T$ & Year & $\mathrm{T}$ \\
\hline 1966 & 13.4 & 1976 & 12.5 & 1986 & 12.7 & 1996 & 12.8 & 2006 & 13.8 \\
\hline 1967 & 13.3 & 1977 & 11.9 & 1987 & 12.4 & 1997 & 13.6 & 2007 & 13.6 \\
\hline 1968 & 13.2 & 1978 & 11.7 & 1988 & 13.8 & 1998 & 13.5 & 2008 & 13.2 \\
\hline 1969 & 13.3 & 1979 & 13.2 & 1989 & 13.1 & 1999 & 13.8 & 2009 & 13.0 \\
\hline 1970 & 12.7 & 1980 & 12.2 & 1990 & 11 & 2000 & 13.2 & 2010 & 13.4 \\
\hline 1971 & 13.4 & 1981 & 12.9 & 1991 & 12.4 & 2001 & 13.7 & 2011 & 14.0 \\
\hline 1972 & 12.7 & 1982 & 13.2 & 1992 & 13.7 & 2002 & 13.7 & 2012 & 13.4 \\
\hline 1973 & 13.0 & 1983 & 13.8 & 1993 & 13.2 & 2003 & 13.6 & 2013 & 13.9 \\
\hline 1974 & 11.9 & 1984 & 12.9 & 1994 & 13.2 & 2004 & 13.1 & 2014 & 13.3 \\
\hline 1975 & 13.6 & 1985 & 13.1 & 1995 & 13.7 & 2005 & 13.9 & 2015 & 12.8 \\
\hline
\end{tabular}

$T$ average air temperature in the growing season in Poland

the analysed multi-year period. By analysing the particular months of the season, it was found that, at $23 \%$ of stations in the whole season, there was less precipitation than the average for the multi-year period. However, at most stations, the rainfall was higher than average in

a

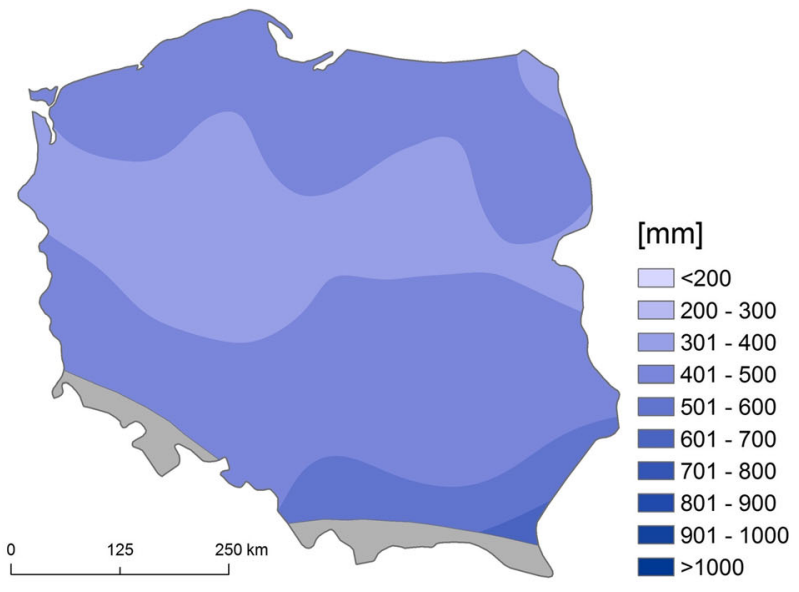

June and May. The largest deviations above the average were recorded in June in Lesko $(60.1 \mathrm{~mm})$ and Hel $(58.9 \mathrm{~mm})$ (Fig. 9). The remaining months were dominated by less precipitation than the multi-year average, and the largest deviations below the average were generally

b

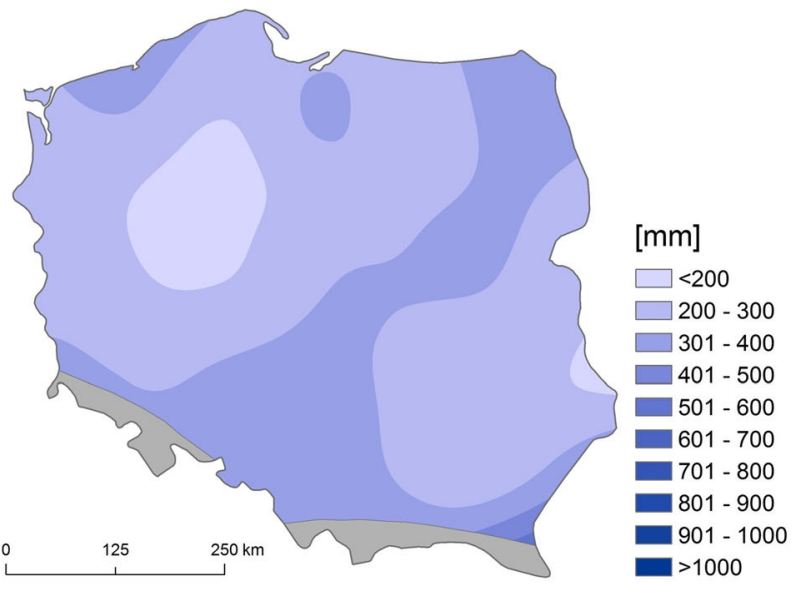

C
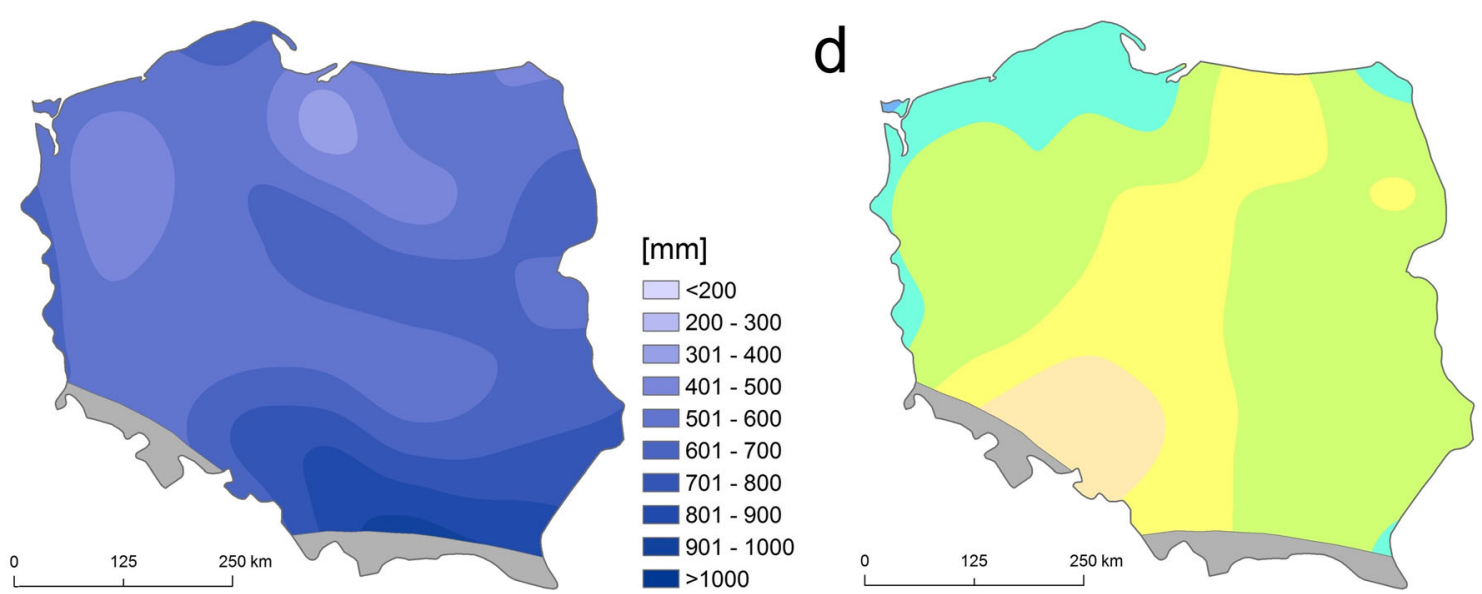

$[\mathrm{mm} / 10$ years $]$

$\square<-10$

$\square-10-0$

$\square 1-10$

$\square 11-20$

$\square>20$

Fig. 8 Average sum of precipitation in the growing season in Poland in the years 1966-2015 (a), sum in 1982 (b), sum in 2010 (c) and change in sum of precipitation (d) 


\section{Elbląg}

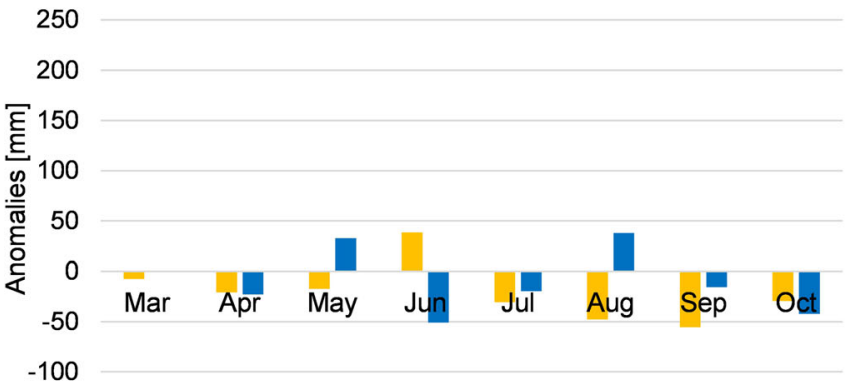

$\mathrm{Hel}$

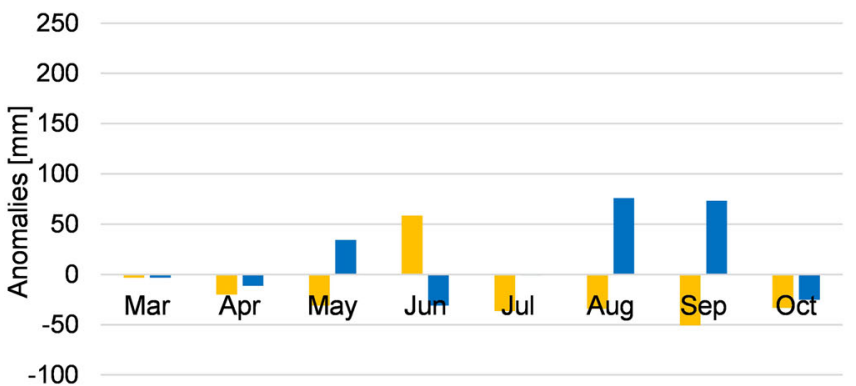

Lesko

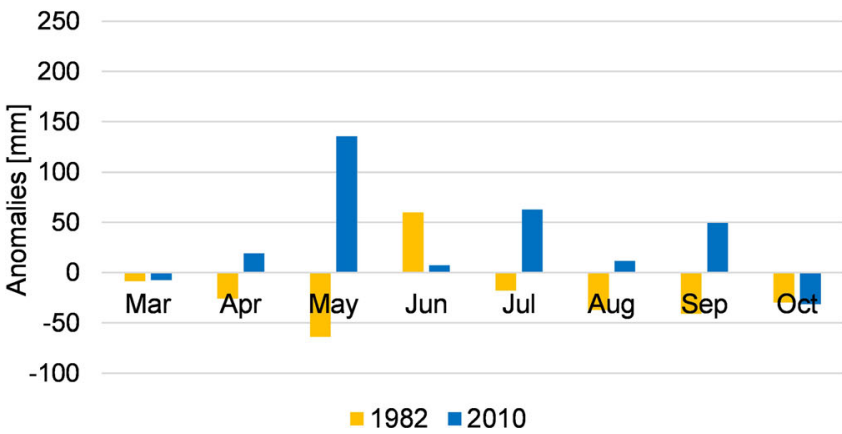

Gorzów Wielkopolski

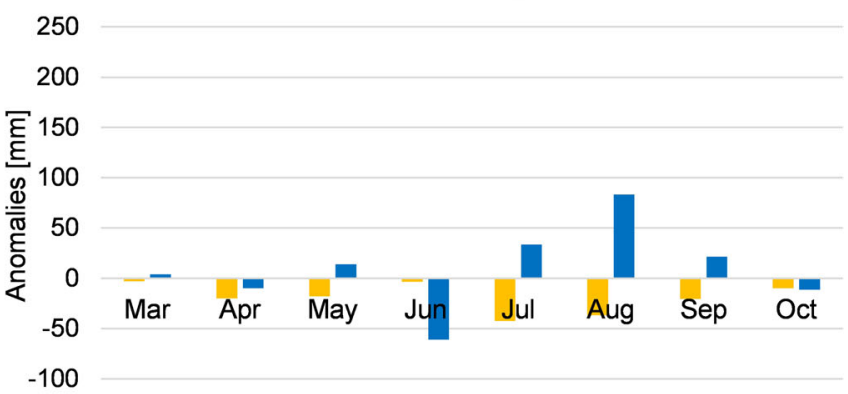

Kraków

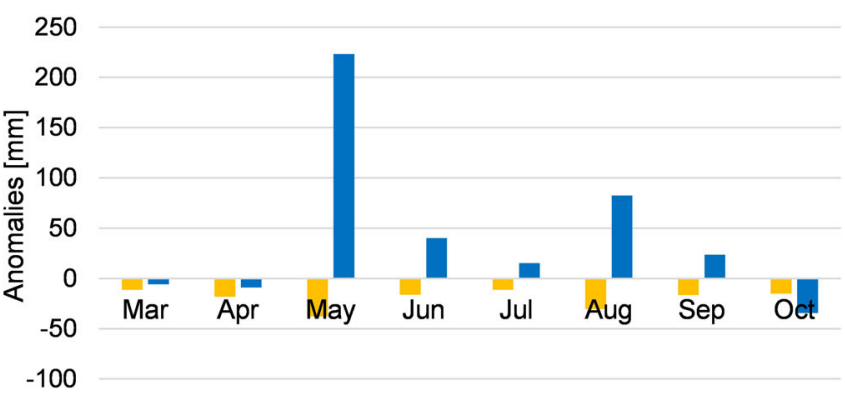

Łeba

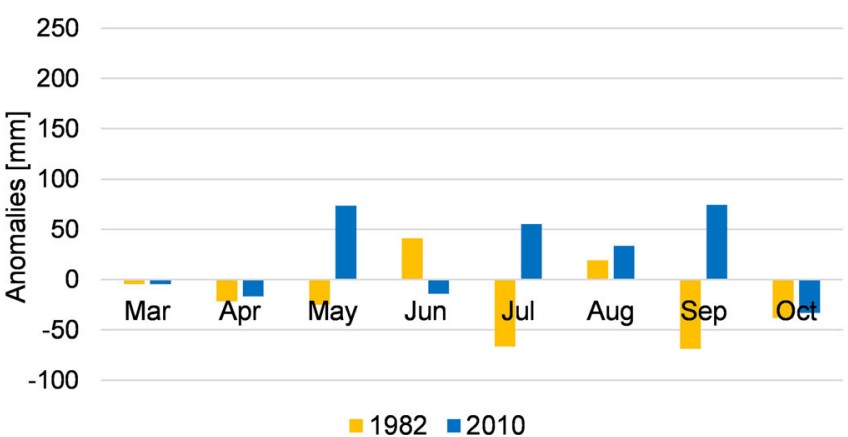

Fig. 9 Anomalies in total rainfall during the growing season in 1982 and 2010

observed in July and September. The maximum deviations exceeded $60 \mathrm{~mm}$ and were recorded in May in Lesko $(63.6 \mathrm{~mm})$, in July in Torun $(64.5 \mathrm{~mm})$ and Warsaw $(63.6 \mathrm{~mm})$ and in September in Kołobrzeg $(62.9 \mathrm{~mm})$ and Łeba $(68.5 \mathrm{~mm})$. In turn, the wettest season was found in 2010 , with the average total being $599.6 \mathrm{~mm}$. The lowest amount of rainfall was recorded in the Lower Vistula region, with the minimum in Elblag, where the seasonal total was $393.7 \mathrm{~mm}$ (Fig. $8 \mathrm{c})$, while the highest precipitation was recorded in the south-eastern regions, with an average of over $700 \mathrm{~mm}$ and the maximum in Lesko $(878.8 \mathrm{~mm})$. In this season, 13 stations experienced their wettest season of the analysed multi-year period. Looking at the individual months of the 2010 season, it was found that, in the early spring and the autumn months, the rainfall was generally lower than the multi-year average. The largest deviations below the average were recorded in June in Gorzów Wielkopolski
$(61.0 \mathrm{~mm})$ and Elblag $(50.9 \mathrm{~mm})$. Deviations significantly above the multi-year average were observed mainly in May, August and September. The maximum positive deviation was $223.2 \mathrm{~mm}$ in May in Kraków. More than $100 \mathrm{~mm}$ was found in May in Lesko $(135.8 \mathrm{~mm})$, Lublin (104.7 mm), Opole (169.4 mm), Racibórz (132.2 $\mathrm{mm})$, in July in Rzeszów $(105.9 \mathrm{~mm})$ and in August in Stubice (189.4 mm).

The change in precipitation in Poland in the years 19662015 is on average high from year to year, but the multiannual increase is not significant (Fig. 8d). In the years studied, an increase in precipitation in the growing season was observed at most stations (Fig. 10). Changes were statistically significant only in Świnoujście at $22 \mathrm{~mm} / 10$ years. In the other coastal stations, a slightly smaller increase was observed (from $14.9 \mathrm{~mm} / 10$ years in Łeba to $16.6 \mathrm{~mm} / 10$ years in $\mathrm{Hel}$ ), although it was significantly higher than in the rest of the country. A reduction in total precipitation was found in the 

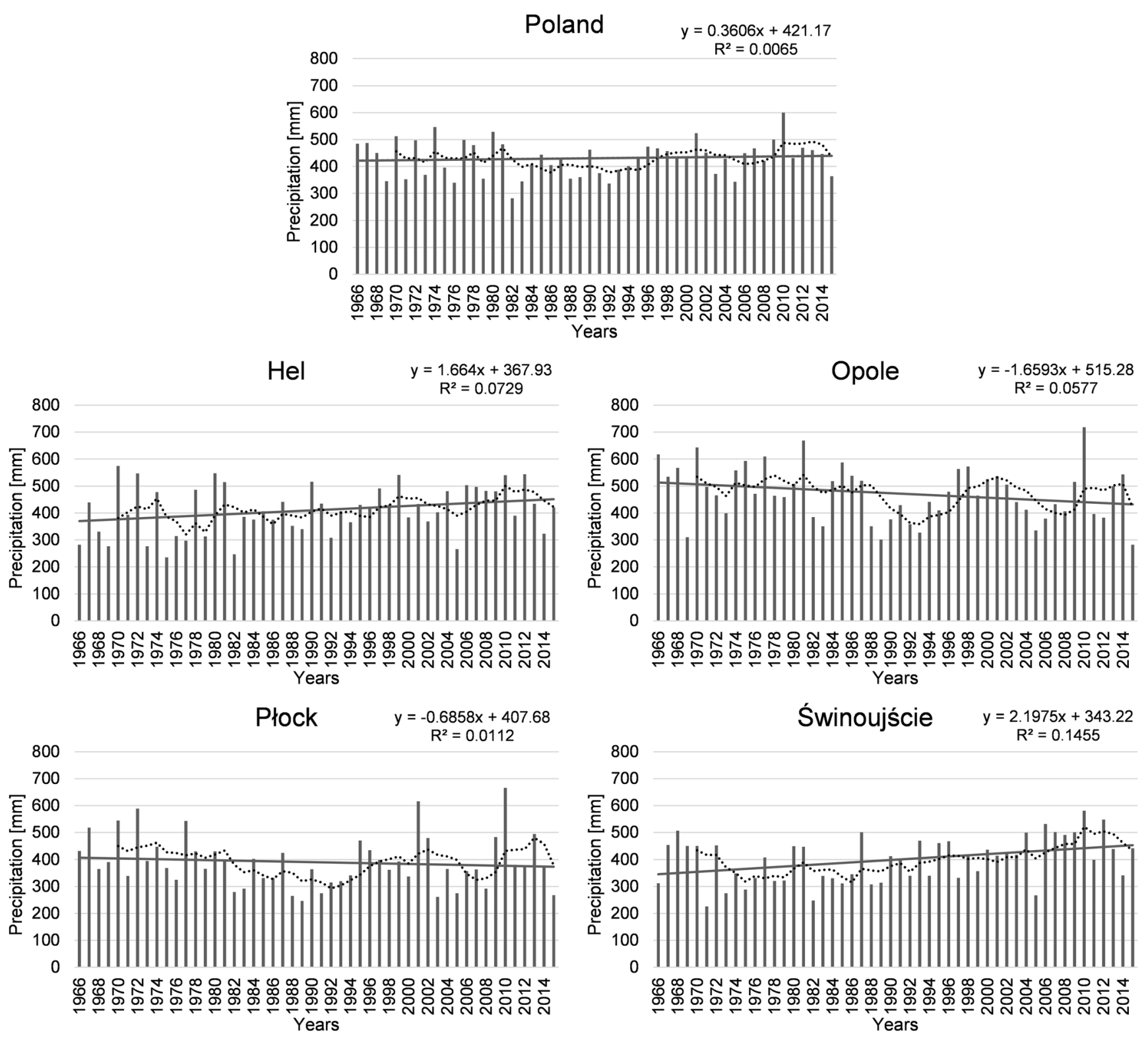

Fig. 10 Sum of precipitation in the growing season in years 1966-2015 at selected stations in Poland (5-year moving average, solid line; linear trend, dotted line)

area extending from the Silesian Lowlands and KrakówCzęstochowa Upland through central Poland to the Masurian Lake District.

Based on the precipitation classification developed by Kaczorowska (1962), it was found that normal conditions prevailed in the analysed years (Table 4). On the basis of averaged data for the whole area, it was stated that normal seasons constituted $48 \%$ of all seasons. Next were dry (26\%) and wet (20\%) seasons. Against the background of the multiyear period, the years 1986-1995 were distinguished, as they featured no seasons with the sum of precipitation above the norm, while four seasons were below the norm. Similar conditions were observed in 1996-2005 but in those years one season was found to be above the norm, while only two were below the norm. In the analysed 50-year period, there were one very dry season (1982) and two very wet seasons (1974, 2010). Precipitation conditions at individual stations were similar to the average in Poland. As a rule, seasons were classified as normal and their percentage ranged from $20 \%$ in Świnoujście to $48 \%$ in Gorzów Wielkopolski. In most stations, the seasons with above-normal precipitation totals occurred most rarely in 1986-1995. Then, single seasons in several stations could be classified as very wet; the very dry seasons occurred much more often. In the analysed multi-year study, extremely dry seasons were observed at some stations in 1971 (Terespol), 1982 (Chojnice, Poznań, Rzeszów) and 2015 (Racibórz). The seasons classified as extremely wet occurred much more often, and these were recorded in 1966 
Table 4 Precipitation classification of the growing season in the years 1966-2015 in Poland

\begin{tabular}{|r|r|r|r|r|r|r|r|r|r|}
\hline Year & P & Year & P & Year & P & Year & P & Year & P \\
\hline 1966 & 484.2 & 1976 & 338.8 & 1986 & 404.5 & 1996 & 473.3 & 2006 & 449.2 \\
\hline 1967 & 486.7 & 1977 & 498.6 & 1987 & 424.8 & 1997 & 467.1 & 2007 & 466.9 \\
\hline 1968 & 450.0 & 1978 & 478.8 & 1988 & 353.9 & 1998 & 456.9 & 2008 & 420.5 \\
\hline 1969 & 345.2 & 1979 & 354.0 & 1989 & 359.8 & 1999 & 430.7 & 2009 & 500.2 \\
\hline 1970 & 512.1 & 1980 & 528.4 & 1990 & 462.0 & 2000 & 434.7 & 2010 & 599.6 \\
\hline 1971 & 351.9 & 1981 & 482.1 & 1991 & 374.6 & 2001 & 523.7 & 2011 & 431.6 \\
\hline 1972 & 496.9 & 1982 & 281.6 & 1992 & 336.6 & 2002 & 451.1 & 2012 & 469.2 \\
\hline 1973 & 368.5 & 1983 & 344.4 & 1993 & 387.9 & 2003 & 371.9 & 2013 & 460.8 \\
\hline 1974 & 546.5 & 1984 & 407.3 & 1994 & 401.2 & 2004 & 428.4 & 2014 & 446.0 \\
\hline 1975 & 395.4 & 1985 & 443.7 & 1995 & 430.2 & 2005 & 342.6 & 2015 & 363.5 \\
\hline
\end{tabular}

$P$ average sum of precipitation in the growing season in Poland

(Kielce, Racibórz, Rzeszów), 1967 (Poznań), 1968 (Racibórz), 1972 (Mława, Płock), 1974 (Lublin, Terespol), 1977 (Mława, Racibórz), 1978 (Olsztyn), 1980 (Chojnice, Toruń), 2001 (Chojnice, Kielce, Płock) and 2010 (Kraków, Opole, Płock, Rzeszów, Siedlce, Słubice, Toruń, Warsaw).

\section{Discussion and summary}

In the years 1966-2015, the growing season in Poland on average started on 26 March and ended on 7 Novemberearliest in the south-west and the latest in the north and north-east. The end of the growing season took place earliest in the north-east, progressing to the south-west and along the north coast. Over the analysed period, the growing season started increasingly early; meanwhile, the end of the growing season was later and later. The recorded changes were statistically significant in the majority of the country except for the north-eastern regions, the Świętokrzyskie Mountains and the Lublin Upland. Results of Nieróbca et al. (2013) show a similar tendency. The increase in the length of the growing season in different regions of Poland was also confirmed by other authors, among others, Żmudzka and Dobrowolska (2001), Kożuchowski and Degirmendžić (2005), OlechnowiczBobrowska and Wojkowski (2006), Skowera and Kopeć (2008), Kijowska (2010), Krużel et al. (2015), Tylkowski (2015) and Graczyk and Kundzewicz (2016). A similar trend of changes has also been observed in other temperate regions, inter alia, in Scandinavia and Finland (Carter 1998; Irannezhad and Kløve 2015) and China (Song et al. 2009).

The thermal conditions of the growing season changed clearly in the analysed multi-year period. In the area of Poland, there was an increase in air temperature during the growing season. Apart from northern Poland and the vicinity of Płock and Białystok, the observed changes were statistically significant at a level of at least 0.05 . The highest increase in air temperature was recorded in southern Poland, with the maximum in Rzeszów ( $0.26^{\circ} \mathrm{C} / 10$ years) and Kraków and Wrocław $\left(0.25^{\circ} \mathrm{C} / 10\right.$ years $)$. A similar trend in most analysed stations in north-eastern Poland was noted by Radzka (2014), where in April, July and August significant changes in air temperature were recorded. The highest increase in this parameter (from $0.6{ }^{\circ} \mathrm{C}$ to $0.8^{\circ} \mathrm{C}$ per 10 years) was observed in April. According to Radzka (2014), in stations in the east of the examined region, a significant temperature increase (from $0.3{ }^{\circ} \mathrm{C}$ to $0.5{ }^{\circ} \mathrm{C}$ per 10 years) also occurred in October. A significant temperature increase occurred, among others, in the warm part of the year and translated into a prolongation of the intensive growing season and a significant increase in thermal resources during the period of active growth of plants (Żmudzka 2012). The increase in temperature at the beginning of the growing season is the reason for the early phenological stages in Poland (Jabłońska et al. 2015). Skaugen and Tveito (2004) forecast a prolongation of the vegetation season due to the expected increase in air temperature in the warm mid-year by 2015 . On the other hand, based on mesoscale data from the Beskids and Foothills, Bochenek et al. (2013) observed a slight downward trend in air temperature $\left(-0.05{ }^{\circ} \mathrm{C} /\right.$ year $)$ during the growing season.

At all stations, there was a marked increase in the frequency of above-normal seasons in the past 20 years, with a simultaneous decrease in seasons falling below normal. There was also a statistically significant increase in total air temperatures in Poland. The smallest changes took place in north-eastern Poland with a minimum in Białystok, $57.5^{\circ} \mathrm{C} / 10$ years. Much more significant changes occurred in western and southern Poland.

Precipitation conditions in the years 1966-2015 did not change so much. Precipitation totals are characterised by high temporal variability. Żarski et al. (2014) find that the greatest variability occurs in August and the authors stress that it causes a climatic risk to growing plants. 
In the years under study, the increase of precipitation in the growing season was observed at most of the stations. However, the changes were statistically significant only in Świnoujście (22 mm/10 years). The remaining coastal stations recorded slightly smaller increases, albeit much higher than in the rest of the country. According to Żarski et al. (2014), a significant trend in the increase in precipitation in Bydgoszcz in the period of 1981-2010 was found only in May. A reduction in total precipitation was found in the area extending from the Silesian Lowlands and Kraków-Częstochowa Upland through central Poland to the Masurian Lake District.

During the growing season in Poland, normal conditions prevailed in the period considered. Extremely dry seasons were observed at some stations. The seasons classified as extremely wet occurred much more often. There were no statistically significant changes found in the studied years.

\section{Conclusions}

In conclusion, it should be stated that in the growing season in Poland in the years1966-2015, there were more significant changes in thermal conditions than in precipitation conditions.

The thermal conditions are characterised by the following:

- increase in the average air temperature in the growing season

- $\quad$ increase in the sum of air temperatures in the growing season

- increasing occurrence of seasons classified as above the norm

Precipitation conditions are characterised by the following:

- no significant changes (except for Świnoujście) in the sum of precipitation in the growing season

- large temporal and spatial variability of precipitation in the growing season

- $\quad$ prevalence of normal conditions

Open Access This article is distributed under the terms of the Creative Commons Attribution 4.0 International License (http:// creativecommons.org/licenses/by/4.0/), which permits unrestricted use, distribution, and reproduction in any medium, provided you give appropriate credit to the original author(s) and the source, provide a link to the Creative Commons license, and indicate if changes were made.

\section{References}

Bartoszek K, Siłuch M (2015) Porównanie metody Gumińskiego i teledetekcji satelitarnej $\mathrm{w}$ aspekcie wyznaczania dat początku okresu wegetacyjnego na obszarze Polski (Comparison of
Gumiński and satellite remote sensing methods in terms of determining the dates of the onset of the growing season in Poland). Inżynieria Ekologiczna 45:99-105 (in Polish)

Bochenek W, Dedo J, Marczewski W (2013) Zróżnicowanie długości i warunków termicznych okresu wegetacyjnego na obszarze Beskidów i Pogórzy w latach 2001-2011 na podstawie danych zgromadzonych w bazie GLDAS (Differentiation of duration and thermal conditions of the vegetation season in the Beskid Mts. and Carpathian Foothill in the period 2001-2011, based on the GLDAS database). Monit Środowiska Przyrodniczego 14:79-85 (in Polish)

Carter TR (1998) Changes in the thermal growing season in Nordic countries during the past century and prospects for the future. Agric Food Sci 7(2):161-179

Chmielewski FM, Rötzer T (2001) Response of tree phenology to climate change across Europe. Agric For Meteorol 108:101-112

Chmielewski FM, Muller A, Bruns E (2004) Climate changes and trends in phenology of fruit trees and field crops in Germany. 1961-2000. Agric For Meteorol 121(1-2):69-78

Czernecki B, Miętus M (2017) The thermal seasons variability in Poland. 1951-2010. Theor Appl Climatol 127(1-2):481-493

Graczyk D, Kundzewicz ZW (2016) Changes of temperature-related agroclimatic indices in Poland. Theor Appl Climatol 124:401-410

Gumiński R (1948) Próba wydzielenia dzielnic rolniczo-klimatycznych w Polsce (Attempt to separate agricultural and climatic districts in Poland). Przegląd Meteorologiczno-Hydrologiczny. Warszawa (in Polish)

IPCC (2013) Climate change: the physical science basis. Contribution of working group I to the fifth assessment report of the intergovernmental panel in climate change. Cambridge University Press, Cambridge

Irannezhad M, Kløve B (2015) Do atmospheric teleconnection patterns explain variations and trends in thermal growing season parameters in Finland? Int J Climatol 35(15):4619-4630

Jabłońska K, Kwiatkowska-Falińska A, Czernecki B, Walawender JP (2015) Changes in spring and summer phenology in Poland-responses of selected plant species to air temperature variations. Pol J Ecol 63(3):311-319

Kaczorowska Z (1962) Opady w Polsce w przekroju wieloletnim (Precipitation in Poland in long-term averages). Prace Geograficzne 33 (in Polish)

Kęińska-Kasprzak M, Mager P (2015) Thermal growing season in Poland calculated by two different methods. Annals of Warsaw University of Life Sciences-SGGW Land Reclamation 47(3):261-273

Kijowska M (2010) Charakterystyka okresu wegetacyjnego w Szymbarku w latach 1968-2009 (Characteristics of vegetation season in Szymbark in the period 1968-2009). Rocznik Świętokrzyski Seria B-Nauki Przyrodnicze 31:29-43 (in Polish)

Kossowska-Cezak U (2005) Zmiany termicznych pór roku w Warszawie w okresie 1933-2004 (Changes of the thermic seasons in Warssaw in the period 1933-2004). Przegląd Geofizyczny 50(3-4):265-277 (in Polish)

Kożuchowski K, Degirmendžić J (2005) Contemporary changes of climate in Poland: trends and variation in thermal and solar conditions related to plant vegetation. Pol J Ecol 53:283-297

Krużel J, Ziernicka-Wojtaszek A, Borek Ł, Ostrowski K (2015) Zmiany czasu trwania meteorologicznego okresu wegetacyjnego w Polsce w latach 1971-2000 oraz 1981-2010 (The changes in the duration of the meteorological vegetation period in Poland in the years 19712000 and 1981-2010). Inżynieria Ekologiczna 44:47-52 (in Polish)

Linderholm HW (2006) Growing season changes in the last century. Agric For Meteorol 137:1-14

Linderholm HW, Walther A, Chen D (2008) Twentieth-century trends in the thermal growing season in the Greater Baltic Area. Clim Chang $87: 405-419$

Lorenc H (1994) Ocena zmienności temperatury powietrza i opadów atmosferycznych w okresie 1901-1993 na podstawie obserwacji z 
wybranych stacji meteorologicznych w Polsce (Assessment of air temperature and precipitation variability in the period 1901-1993 on the basis of observations from selected meteorological stations in Poland). Wiad IMGW 38:43-59 (in Polish)

Menzel A, Fabian P (1999) Growing season extended in Europe. Nature 397:659

Nieróbca A (2009) Skutki zmian klimatycznych dla rolnictwa w Polsceocena zagrożeń (The effects of climate change on agriculture in Poland—risk assessment). In: Kozyra J, Nieróbca A, Mizak K (eds) Zmiany klimatyczne a rolnictwo w Polsce — ocena zagrożeń i sposoby adaptacji. IUNG-PIB, Puławy (in Polish)

Nieróbca A, Kozyra J, Mizak K, Wróblewska E (2013) Zmiana długości okresu wegetacyjnego w Polsce (Changing length of the growing season in Poland). Woda-Środowisko-Obszary Wiejskie 13, 2(42): 81-94 (in Polish)

Olechnowicz-Bobrowska B, Wojkowski J (2006) Okresy termiczne w południowej części Wyżyny Krakowsko-Częstochowskiej (19912000) (Thermal periods in the southern part of the CracowCzęstochowa Upland (2000)). In: Trepińska J, Olecki Z (eds) Klimatyczne aspekty środowiska geograficznego, Instytut Geografii i Gospodarki Przestrzennej UJ, Kraków, pp 51-61 (in Polish)

Radzka E (2013) Okresy termiczne w środkowo-wschodniej Polsce (1971-2005) (Thermal periods in Central-eastern Poland (19712005)). Acta Agrophysica 20(4):679-691 (in Polish)

Radzka E (2014) Tendencje zmian temperatury powietrza okresu wegetacyjnego w środkowo-wschodniej Polsce (1971-2005) (Tendencies of air temperature changes of vegetation period in central-eastern Poland (in the years 1971-2005)). Acta Agrophysica 21(1):87-96 (in Polish)
Skaugen TE, Tveito OE (2004) Growing season and degree-day scenario in Norway for 2021-2050. Clim Res 26:221-232

Skowera B, Kopeć B (2008) Okresy termiczne w Polsce południowowschodniej (1971-2000) (Thermal periods in south-eastern part of Poland (1971-2000)). Acta Agrophysica 12(2):517-526 (in Polish)

Song Y, Linderholm HW, Chen D, Walther A (2009) Trends of the thermal growing season in China. 1951-2007. Int J Climatol 30:33-43

Szyga-Pluta K (2011) Termiczne pory roku w Poznaniu w latach 20012008 (Thermal seasons in Poznań in the period 2001-2008). Przegląd Geograficzny 83(1):109-119 (in Polish)

Tylkowski J (2015) The variability of climatic vegetative seasons and thermal resources at the Polish Baltic Sea coastline in the context of potential composition of coastal forest communities. Balt For 21(1):73-82

Żarski J, Dudek S, Kuśmierek-Tomaszewska R, Bojar W, Knopik L, Żarski W (2014) Agroklimatologiczna ocena opadów atmosferycznych okresu wegetacyjnego w rejonie Bydgoszczy (Agro-climatological assessment of the growing season rainfall in the Bydgoszcz region). Infrastruktura i Ekologia Terenów Wiejskich 3(II):643-658 (in Polish)

Żmudzka E (2012) Wieloletnie zmiany zasobów termicznych w okresie wegetacyjnym i aktywnego wzrostu roślin w Polsce (Long-term changes of thermal resources in the vegetative period and the active growth of plants in Poland). Woda-Srodowisko-Obszary Wiejskie 12, 2(38):377-389 (in Polish)

Żmudzka E, Dobrowolska M (2001) Termiczny okres wegetacyjny w Polsce-zróżnicowanie przestrzenne i zmienność czasowa (Thermal vegetation in Poland - spatial and temporal variability). Przegląd Naukowy Wydziału Inżynierii i Kształtowania Środowiska SGGW 21:75-80 (in Polish) 